\title{
War of words over future of Berlin teaching hospitals
}

Munich. The Free University of Berlin seems likely to lose its fight to stop one of its two teaching hospitals being transferred to Humboldt University in the east of the city. Last week, the Christian Democrat faction of Berlin's city government proposed a bill that would lead to a transfer next April.

But the Free University, in the former West Berlin, is fighting to retain at least some control over the hospital. The dispute has become a bitter power struggle between the two universities, fanned by concern over the financial cuts being imposed on institutions in the west of the city to support the strengthening of those in the east.

Reunification of the city after the fall of the Berlin wall in 1989 quickly turned the west half from a rich and privileged (if isolated) city, heavily subsidized by the federal government in Bonn, into one marked by social unrest, economic collapse and political turmoil.

The highest priority of the Berlin government is now to save money, and the ministry of science and research has been given the urgent task of rationalizing the city's three universities. Most of the required department mergers have now been achieved (see Nature 363, 198; 1993). But the issue of the teaching hospitals has continued to fester.

In March, the ministry decided to recommend the merger of two such hospitals the Charité, belonging to Humboldt University, and the Rudolf Virchow Hospital, belonging to the Free University - under the management of Humboldt University. (The Free University's Steglitz Hospital, with about 1,200 beds, would remain where it is.)

The ministry wants the Charité to eliminate 150 beds and the Rudolf Virchow 200, leaving them with 1,200 and 1,150 beds respectively, and the total number of staff in both hospitals to be reduced by natural wastage over the next few years (a target number has not yet been defined).

It also wants an estimated DM1.6 billion (US\$960,000) for building repairs and modernization of the Charité to be reduced by sharing facilities and equipment with the Rudolf Virchow hospital, whose new buildings are only $2 \mathrm{~km}$ away.

Complying with Humboldt University's wish to complete the post-reunification reassessment of all staff before merging departments, the ministry suggests as a first step the transfer of the management of the Virchow hospital to Humboldt University in April next year.

The Christian Democrat faction of Berlin's coalition government last week put forward a draft bill based on the ministry's suggestions. Details are being discussed with its coalition partners, and the bill is expected to go to parliament for approval in the next few weeks.

But the proposals have not gone down well with the Free University, unhappy about losing control over a teaching hospital in which it has invested nearly DM2 billion in the past 10 years.

Vice-president Peter Gaehtgens, a physiologist, says that the decision to leave the Free University with only a single hospital would put the university at an unfair scientific disadvantage compared to Humboldt, as the loss of the Virchow hospital would result in preclinical teaching and research resources at the university being cut by twothirds.

Gaehtgens says it is unclear how the ministry's proposals would save money. Together with the president, Johann Gerlach, he wants the ministry to produce a detailed financial plan showing that, by giving up its hospital, the university will be saving Berlin a considerable amount of money.

Furthermore, if the ministry's only motivation is to save money, it should be proposing an immediate merger, rather than waiting for the Charité to reappoint its professors, as this will reduce its room for manoeuvre during the later merger, says Gaehtgens.

In reply, the ministry argues that savings will come from the proposed cuts in beds and staff, but says it cannot provide exact figures until negotiations are complete.

The Free University has put forward counter-suggestions, such as a merger of all three teaching hospitals into a single medical school independent of the three universities, or even merging the Humboldt and Free universities along the lines of the multisited University of London. But the ministry does not consider either suggestion to be practical in the present situation in Berlin.

Tempers are running high. Gerlach and Gaehtgens have attacked the ministry's proposals for merging the hospitals as "dishonest, deceitful and irresponsible". Manfred Erhardt, Berlin's science minister, has hit back by saying that they are using colourful language to hide the weaknesses of their arguments, dismissing the critics as "two commanders condemning an enemy to whom most of their troops have already defected".

The Free University is unlikely to succeed in its fight, as this would disrupt overall plans for restructuring the university system in Berlin, and bringing Humboldt up to the academic standards in the west. But the bitterness of the conflict, given the general maelstrom of changes in Germany's future capital, is trying the nerves of all involved, while politeness and tolerance have been relegated to the past.
Alison Abbott

\section{US unveils details of $\$ 750$ million technology plan}

Washington. The National Institute of Standards and Technology (NIST), part of the US Department of Commerce's Technology Administration, last week fleshed out its proposal to provide focused support on a cost-sharing basis to industrial research and development projects in five key areas of technology.

Areas chosen for this five-year, \$745million Advanced Technology Program (ATP) initiative include DNA-based diagnostics, the manufacture of composite structures, the development of an information infrastucture for the health-care sector, computer-integrated manufacturing for electronics, and the development of componentbased software.

For the current fiscal year, the total budget for the ATP is just under $\$ 200$ million, an almost three-fold increase over last year. The ATP is due to receive further major increases under President Bill Clinton's Economic Plan which, if approved by Congress, would increase its budget to almost $\$ 750$ million by 1997 .

The goal of the ATP is to support new technologies with a high level of technical risk, but with significant commercial potential, that private and public investors might be reluctant to back. Proposals are invited from single companies or joint ventures consisting of at least two for-profit companies.

Although the ATP's focus on private companies is what distinguishes it from other forms of federal funding, universities, government laboratories and other non-profit organizations can still apply for support, either as subcontractors to single companies, or to a joint venture. Such organizations can receive payment from companies in recognition of their contribution. But title to any patents resulting from ATP-sponsored research must be held by a company incorporated in the United States.

Some are finding this legislativelymandated provision particularly hard to swallow. Lita Nelsen, director of the Technology Licensing Office at the Massachusetts Institute of Technology (MIT), says that it does not believe the restriction is appropriate, "nor do we believe it was the intent of Congress". A technical amendment clarifying the original intention of the law is now pending in Congress. But until such time as the law is changed, Nelsen says MIT remains reluctant to enter into such agreements.

The \$145-million "Tools for DNA Diagnostics" competition invites proposals that will lead to development of new diagnostic methods, instrumentation and data-management tools designed to speed up DNA analyses and drive down costs by an order of

magnitude or more.
Diane Gershon 